\title{
SHAPING THE RELATIONSHIPS OF YOUNG CONSUMERS BASED ON VIDEO CONTENT IN THE SOCIAL MEDIA ENVIRONMENT IN THE LIGHT OF DATA CLUSTERING
}

\author{
URSZULA CHRĄCHOL-BARCZYK, ${ }^{1}$ MATEUSZ GRZESIAK ${ }^{2}$ \\ ${ }^{1}$ University of Szczecin, Faculty of Management and Economics of Services, POLAND \\ e-mail: urszula.chrachol@wzieu.pl \\ 2 University of Business in Dabrowa Górnicza, WNS, POLAND \\ e-mail: mgrzesiak@wsb.edu.pl
}

RECEIVED
ACCEPTED

JEL

CLASSIFICATION

KEYWORDS

ABSTRACT
10 December 2018

28 December 2018

L82, L86, M31

social media, relationship building, consumer, television, cluster analysis

Continuous progress in all areas of life affects the decision-making processes of the society and their consumption decisions. In recent years, through constant technological development, a continuous drop in television viewing has been observed. Individual television stations, multimedia service providers, however, try to regain the viewer and create websites and applications for mobile devices in which you can watch live TV, play programs or movies at any time or see episodes that will be played in television in the future. The Polish VoD market, social media and YouTube are undoubtedly market leaders, which compete with traditional television and even become its replacement. The aim of the article is to show that the following changes in the market, change consumer habits among buyers, with particular emphasis on young people, in the field of video in relation to classic television, YouTube, streaming platforms and social media. The article uses own research, which was carried out on the basis of cluster analysis. Based on profiling of social media users, due to the selected characteristics, five clusters were obtained, each of which describes a certain YouTuber profile

\section{Traditional television and its popularity}

Undoubtedly, classic television belongs to the mass communication tools because through it can reach a wide audience with transmitted content and with advertising content. Traditional television has already had years of greatest popularity and has been recording declines in viewership for a long time. The managers of the individual stations compete in making creative programs, series, films, just to attract the viewer in front of the TV set. 
The development of technology, however, means that viewers are moving away from traditional television viewing in favor of vod solutions, other paid platforms for video viewing and social media. In addition, it starts to create series and programs that are available to the viewer only on specific streaming platforms. TV stations perceive progressive changes among viewers in the search for a variety of content on the web, not television. In addition, there is a steady increase in the use of tablets, smartphones and laptops on the market, which "discriminates" classic TVs. This is especially true for generations of young people. Mass communication can be examined by focusing mainly on selected issues, analyzed from the point of view of the sender and the recipient, referring to the information content and the effectiveness of the means used and information methods. Most often, two problems emerge: the first concerns the transmission of information, determining how effective the media is, who is reached with the information, whether there are gaps, social groups lacking information, and the second measuring the power of information transmission on shaping attitudes and social opinions and ways of behavior (Światowy, 2006, p. 122). As clear from the data of the Nielsen Audience Measurement (April 2018), which studies TV viewing in Poland, the television viewers' projections developed by the Wirtualnemedia.pl portal are falling, which is detailed in Table 1.

Table 1. TV audience in April 2017 and 2018

\begin{tabular}{ccccccc}
\hline \multirow{2}{*}{ Wirtualnemedia.pl } & \multicolumn{5}{c}{ All 4+ } & \multirow{2}{*}{ Dynamics } \\
\cline { 3 - 6 } & \multicolumn{3}{c}{ April-17 } & \multicolumn{2}{c}{ April-18 } & \\
\hline no. & station & AMR & SHR $\%$ & AMR & SHR \% & $\%$ \\
\hline 1. & Polsat & 733274 & 11.17 & 625114 & 10.47 & -6.27 \\
2. & TVN & 684195 & 10.42 & 561622 & 9.41 & -9.69 \\
3. & TVP1 & 578431 & 8.81 & 524778 & 8.79 & -0.23 \\
4. & TVP2 & 516437 & 7.87 & 497794 & 8.34 & 5.97 \\
\hline
\end{tabular}

Source: Kurdupski (2018).

The results compare TV audience in April 2017 and 2018 indicating its negative dynamics. This trend is constantly being analyzed by other research results, year-on-year. These surveys are usually carried out every month, their results are similar, the seasonal trends of popularity of individual TV stations, selected programs and series are visible.

\section{Social media, streaming plattornms, YouTube as the successor of traditional television}

Social media are an indispensable element of modern times. Social media means applications that are created in a Web 2.0 environment and progressive technological development, the purpose of which is to interact with their users. The exchanged content has a diverse form from text messages through photos, video, insight, and live coverage. A great example of how social media and TV are constantly changing is the first in Poland advertising made "live" by Skoda (issue 6/10/2018), which was also live on TVN (contextual broadcast as part of the "Got Talent" program), in social media channels, on leading internet portals, at sales points, the cinema and on influencers' channels. Each of the above mentioned forms, depending on the specific medium, has many own variants. Along with their development, their functionality changes, and so does the way users use them. Social media are increasingly becoming a substitute for traditional television. Deciding by the user what content and in what form he/she wants to watch fits into the assumptions of the theory of use and gratification derived from functionalist 
(behavioral) tradition, which for 80 years has been a research facility for scientists who are trying to find out why and what for the people use the media. Theory of use and gratification assumes that people are aware of their needs and are oriented towards achieving specific goals. They actively search for such media and content that are able to meet their expectations and provide appropriate reinforcements, that is various types of individual prizes (gratuities) (Iwanowska, 2016, pp. 171-172). The consumers of younger generation often change this shopping behavior by using the Internet while shopping. Thanks to Internet access and mobile technologies, the virtual world is as important and attractive for the Millennials as the real world (Bilińska-Reformat, Stefańska, 2016, p. 124).

On the basis of many reports from surveys that occur on the market, it appears that for several years each subsequent year is a year of video, because on the basis of observations of companies' activities on the market, there is an increasing focus on video marketing. This is because of the awareness of the availability and efficiency of this form, the possibilities of formats on Facebook and Google, both for smaller and larger companies, and $89 \%$ of Internet users primarily watching video content (Kuchta, 2018). Attractive spots can fall into the recipient's memory for a long time, and their potential to present the product is really big. A number of possibilities to show yourself through a moving image are provided by YouTube and Facebook. Network users spend a billion hours a day watching movies, and according to Cisco, by $2019,80 \%$ of Internet traffic will be just video. Considering that it is more difficult to catch the attention of the recipient in the network with the help of text, creating engaging video is a direction that should be taken so that the actions are effective. Influencers who are authentic and for whom the internet is a natural environment are especially helpful in this. The following data indicate that video (video marketing) is not just a buzzword, because (Odziemek, 2018, p. 60):

- $67 \%$ of recipients want to watch instructional videos and tutorials and $34 \%$ of product and information films (Marketing Think),

- in $2018,79 \%$ of video content will constitute the Internet (MarketingProfs),

- $64 \%$ of consumers purchase after watching the video on social media (Tubular Insights),

- Facebook video posts have up to $135 \%$ more organic coverage than Social Media Today,

- video on social media can generate as much as $1200 \%$ more shares than text posts and photos (SmallBizTrends).

According to Katarzyna Legutko from ContentHouse, "users will definitely appreciate a film made with a simple camera or a phone that meets their needs, rather than a television advertisement" glued "to the Internet" (Kuchta, 2018) The confirmation of this fact comes also from the PwC survey results carried out in December 2016 among Internet users, according to which a statistical internet user in Poland to watch video content - on TV or on the Internet - spends 4 hours a day. The most popular video content website is YouTube $-74 \%$ of respondents declared the use of it, followed by TV Polsat (44.8\%), Player.pl from TVN (33\%) (Pallus, 2017). Popular Facebook or Instagram (IGTV) also offers its users inserting videos of various lengths, content, recorded either by means of telephones or specialized equipment. In these media, there is also the possibility of "live broadcasting". Facebook is currently testing the functionality of watching together, for example, a match or movie with someone else who is not sitting next to just your device, e.g. in another country. Another alternative for traditional television are streaming platforms, which have been developing significantly over the last few years. Based on the research conducted in April 2018 by Gemius, it appears that among all streaming platforms the most users had Vod.pl - over 3.7 million people. Next in the ranking are cda.pl (premium version, 2.6 million users), tvp.pl (2.4 million users) and player.pl (2.3 million users), Netflix (2 million users), Ipla (1.8 million users), wp.pl (1.7 million users), Showmaks (1.3 million users) and HBO 
GO (1 million users). The VoD market combines materials typical of classic television as well as large productions for premium cinema and VoD services (Czechowicz, 2018a). YouTube is a platform that users use in an intentional manner. Most often, they search for films in person, but they can also use YouTube's recommendations. It is a great platform for content-marketing communication and gives a wide range of advertising opportunities. (Daniłoś, 2018, p. 58) Streaming platforms differ in many respects from YouTube. Their range of activities is wide but due to the subject matter of the article, they can be divided in terms of video content and their implementation. The first group allows to watch movies, series, programs - all these forms are recorded in a professional manner, are planned, have scenarios. On the other hand, on YouTube (and its similar channels) there are videos uploaded by users of the site, often shot in a much less professional way - often using phones, laptops, etc. on all possible topics of interest among the channel's recipients. First and foremost, there are accounts of well-known people who publish their statements on various topics: they advise, train, inspire, motivate, teach, make us laugh. The element that connects these media is their constant development - they improve their offer to attract the largest group of recipients to their medium.

For example, on YouTube, videos are uploaded by users, this service has movies on demand and recently in the US has already introduced the option of watching some materials for free. It is certainly a desire to offer services similar to Vod and it will probably be transferred to the European area over time. (Czechowicz, 2018b) A few months ago, YouTube Kids appeared in Poland - which reminds more of the vod platform than YouTube. Children can safely and easily discover the world by watching movies online - regardless of whether it is their favorite story, song or educational film showing how to make a volcano model. (Luzak, 2018). The results of Kantar Millward Brown's research Generation Z, Millenials, Generation X, Baby Boomers: what role television plays in their lives (implementation December 2017 to February 2018 using the CAPI method on a group of 612 respondents) showed that each of the surveyed groups uses Facebook the most (Generation Z 98\%, Millenials $86 \%$, Generation X $52 \%$, Baby Boomers 17\%) then YuoTube (Generation Z 92\%, Millenials 73\%, Generation X 47\%, Baby Boomers 19\%) and Instagram (Generation Z 49\%, Millenials 25\%, Generation X 11\%, Baby Boomers 3\%). The Netflix platform ranked seventh (Generation Z 11\%, Millenials 12\%, Generation X 5\%, Baby Boomers 1\%) and Showmax (Generation Z 8\%, Millenials $11 \%$, Generation X $3 \%$, Baby Boomers $0 \%$ ). The respondents were also asked how much time they spend on social networking sites during the ordinary day? The following times were indicated: Generation Z 36 minutes (real daily time per user $2 \mathrm{~h} 05 \mathrm{~m}$ ), Millenials 34 minutes (real daily time per user $1 \mathrm{~h} 36 \mathrm{~m}$ ), Generation X 31 minutes (real daily time per user $36 \mathrm{~m}$ ), Baby Boomers 10 minutes (real daily time per user $25 \mathrm{~m}$ ). In the younger groups, the leading role is played by laptops and smartphones.

\section{Methodology and results of own research}

Cluster analysis assigns objects to groups to allow for the greatest possible similarity within groups and the largest differences between them (Churchill, 2002, p. 827). Based on the variables characterizing the examined objects, these methods allow the extraction of object classes that are more similar to objects from the same clusters than to objects from other clusters. (Muszyński, Mrozik, 2009, p. 24) In own research, as an analytical tool, a cluster analysis method was proposed to classify objects. As a result of the analysis of profiling of social media users (age group 18-34) due to specific characteristics (age, gender, current job situation, the best tool for building a personal brand due to a set of features, impact of the personal brand on different areas of the respondent's life, popular 
topics on YouTube, preferred actions on YouTube, compliance with various statements regarding YouTube, building a personal brand with the definition presented) five clusters were received. As a method of agglomeration, the Ward method was adopted, while as a measure of the distance between objects - a measure of percent discrepancy (as variables are measured on categorical measuring scales: nominal and ordinal). 504 respondents took part in the survey. The first cluster consists of $7.5 \%$ of respondents, the second cluster includes $12.1 \%$, the third cluster $20.4 \%$, the fourth cluster $21.4 \%$ and the fifth cluster $38.5 \%$. Respondents were asked to state their compliance with the statement: I have more confidence in YouTube than television and other traditional media. The respondents of the first cluster declare that they agree (57.9\%) with the quoted statement (Figure 1). Slightly more than $18 \%$ of respondents indicate that they disagree with this statement.

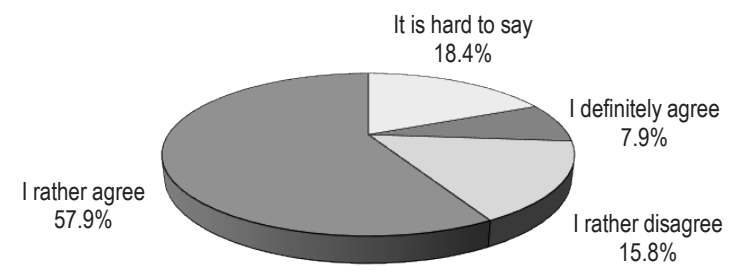

Figure 1. I have more confidence in YouTube than TV and other traditional media - first cluster

Source: own elaboration.

The respondents from the second cluster strongly agree with the quoted statement (54.1\%) - Figure 2. Nearly $20 \%$ of respondents indicate that they rather agree. Only $6.6 \%$ of respondents negate. $19.7 \%$ indicated the "it's hard to say" option.

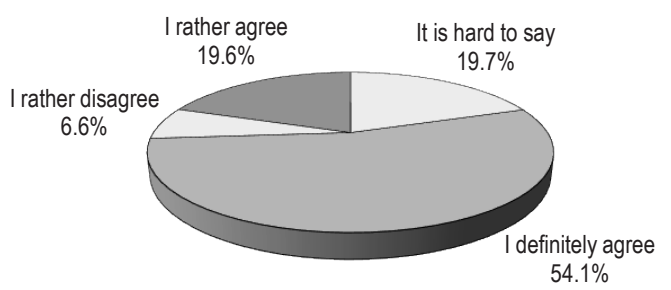

Figure 2. I have more confidence in YouTube than TV and other traditional media - second cluster Source: own elaboration.

Respondents (third cluster) in the largest percentage indicate that they tend to agree (38.8\%) or they find difficult to express an opinion (25.2\%) regarding the analyzed statement. The clear agreement is indicated by $24.3 \%$, while the total incompatibility is represented by only $1 \%$ of the respondents. 


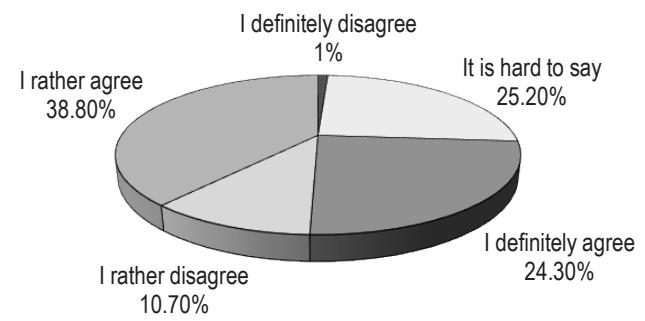

Figure 3. I have more confidence in YouTube than TV and other traditional media - third cluster

Source: own elaboration.

The respondents representing the fourth cluster in the largest percentage indicate that they have no opinion on the analyzed topic (40.7\%). The "rather agree" option was given by $28.7 \%$ of the respondents from this group. The total lack of conformity was indicated by $10.2 \%$ of respondents.

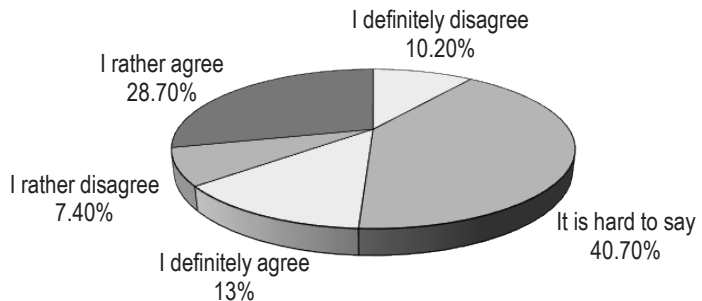

Figure 4. I have more confidence in YouTube than TV and other traditional media - fourth cluster

Source: own elaboration.

Participants in the study (fifth focus) in the largest percentage indicate that it is difficult for them to express an opinion on the analyzed statement (37.1\%). The "I rather agree" and "I strongly agree" option was indicated by $25.3 \%$ and $21.1 \%$ of respondents, respectively. The total negation was represented by $5.7 \%$.

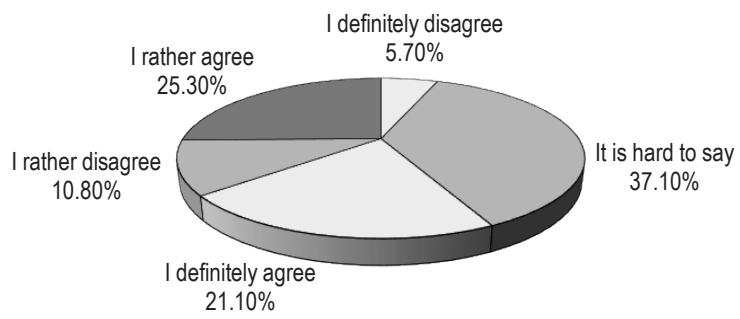

Figure 5. I have more confidence in YouTube than TV and other traditional media - the fifth cluster

Source: own elaboration. 
Summing up the presented results of own research it can be stated that the vast majority of respondents agree with the statement that they have more confidence in YouTube than television and other traditional media. It is worth noting that among the respondents there are few who have chosen the answer that they strongly disagree with this statement. The results of our own research confirm the changes taking place on the market, which were described in the first part of the article. Society (to varying degrees in specific age groups) is moving away from traditional television and is looking for alternatives in solutions available on the market.

\section{Conclusions}

The occurrence of new functionality in a specific social media forces competing applications to introduce something similar or much more advanced than the competition has. In addition, trends operating and appearing on the market among users, divided into their generation, should be observed. The presented results of secondary and own research suggest the following conclusions. First of all, the consumer determines what he/she needs and at what time and place he/she wants to use it. Secondly, the video with the appropriate content is the content desired by the recipients analyzed in the media article. Thirdly, traditional television is losing in importance and YouTube, streaming platforms and other social media are gaining. The popularity of YouTube also results from the fact that more and more often young people are looking for video with people they trust, which they want to listen to because they are known and liked and are more credible, even when telling them about a product or recommending a book than advertising in television. Due to such a large competition, each application must build relationships with its users, meet their expectations to use the solution as long as possible and not to reach for a competitive medium. Certainly, it is not a simple task because the statistics of use in the described media change but also indicate a continuous interest in them from the audience. Apart from the competition analysis, the creators of individual media should carry out continuous research among their recipients, asking them about their needs in relation to a given medium. In the future, own research should be extended to the most-watched and sought-after content in the analyzed media by young people and their assessment of media functionality - what they use, which is unnecessary and what they lack.

\section{References}

Bilińska-Reformat, K., Stefańska, M. (2016). Young Consumer's Behaviours on Retail Market and Their Impact on Activities of Retail Chains. Business Excellence, October, 123-136. Retrieved from: https://www.ue.katowice.pl/fileadmin/user_upload/WZ/ katedry/kat-zarz-market-i-turyst/Bilinska-Reformat_K_and_Stefanska_M._BE_2016.pdf.

Churchill, G.A. (2002). Badania marketingowe. Podstawy metodologiczne. Warszawa: Wydawnictwo Naukowe PWN.

Czechowicz, B. (2018a). Polski rynek VoD: jak wyglada w 2018 roku? Retrieved from: https://www.komputerswiat.pl/artykuly/redakcyjne/ polski-rynek-vod-jak-wyglada-w-2018-roku/pkh3rhr.

Czechowicz, B. (2018b). YouTube wprowadza darmowe, pełnometrażowe filmy. Retrieved from: https://pclab. pl/news79281.html.

Daniłoś, M. (2018). Jak wygenerować więcej wyświetleń na YouTube? 7 praktycznych pomysłów. Social Media Manager, 2 (5), 56-58.

Iwanowska, M. (2016). Zrozumieć media (społecznościowe). Pespektywa psychologiczna. In: M. Łosiewicz, A. Ryłko-Kurpiewska (eds.), Media. Biznes. Kultura. Rzeczywistość medialna. Formy, problemy, aspiracje (pp. 169-185). Gdańsk: Novae Res.

Kuchta, M. (2018). Raport "Social media to nowa telewizja". Zobacz, jak wideo w internecie wygrywa z telewizja. Retrieved from: https:/l socialpress.pl/2018/04/raport-social-media-to-nowa-telewizja-zobacz-jak-wideo-w-internecie-wygrywa-z-telewizja.

Kurdupski, M. (2018). Polsat i TVN liderami w kwietniu. Seriale TVP2 ratingowymi hitami. Retrieved from: https://www.wirtualnemedia. pl/artykul/ogladalnosc-telewizji-kwiecien-2018-polsat-liderem-hity-seriale-tvp2.

Luzak, B. (2018). YouTube Kids w końcu w Polsce: dzieciaki dostały własną platformę VOD! Retrieved from: https://yt360.pl/youtube-kids. 
Muszyński, A., Mrozik, A. (2009). Klasyfikacja zasobów budynkowych gminy metodą analizy skupień. Studia i Materiały Towarzystwa Naukowego Nieruchomości, 17 (4), 23-36.

Odziemek, K. (2018). Wideo marketing dla każdego - o czym pamiętać, jak zaplanować działania i czego używać? Social Media Manager, 2 (5), 59-62.

Pallus, P. (2017). YouTube i wideo rosną w siłę. Internauci nie rezygnują z TV i sami chcą kształtować pakiety kanałów. Retrieved from: https://businessinsider.com.pl/media/youtube-popularnosc-wideo-w-telewizji-i-internecie-raport-pwc/ywqr0r4.

Światowy, G. (2006). Zachowania konsumentów. Determinanty oraz metody poznania i kształtowania. Warszawa: PWE.

Cite this apticle aS: Chrąchol-Barczyk, U., Grzesiak, M. (2018). Shaping the relationships of young consumers based on video content in the social media environment in the light of data clustering. European Journal of Service Management, 4 (28/2), 97-104. DOI: 10.18276/ ejsm.2018.28/2-11. 